\title{
EFFECT OF CYTOCHROME P450 1A1 (CYP1A1) POLYMORPHISM ON ASPHALT EXPOSURE - RELATED BIO-MARKERS
}

\author{
By \\ Farahat S.A.*, Rashed L.A.**, Helal S.F.*, Abdel Maksoud N.* \\ FROM \\ * Department of Occupational Medicine \& Industrial Diseases. \\ ** Department of Biochemistry. \\ Faculty Of Medicine . Cairo University.
}

\begin{abstract}
Asphalt fumes contain polycyclic aromatic compounds (PAC). There is a possibility of long-term health effects following chronic exposure by inhalation or skin contamination in asphalt road pavers. Objective: This study aimed at exploring the relationship between urinary 1-OH pyrene as a marker of internal dose of PAHs exposure and serum P53 protein as a response marker with the genetic polymorphism of CYP1A1 as a susceptibility marker among asphalt exposed workers. Methods: This work included 70 male individuals who were divided into an asphalt exposed group $(n=43)$ and a matched control group $(n=27)$. The exposed group was further subdivided into a group of paving and mixing $(n=24)$ and a group of roller and vehicle drivers $(n=19)$. Every participant was subjected to polymerase chain reaction $(\mathrm{PCR})$ technique to detect the different genotypes of CYP1A1 gene and the expression of the p53 gene mutation. Besides, estimation of urinary 1-hydroxy pyrene (1-OHP) and serum level of mutant p53 protein was done as a PAHs exposure and response biomarkers, respectively. Results: CYP1A1*2A (Valine / Valine) was found to be the most prevalent CYP 1A1 genotype among both exposed and control groups. It was associated
\end{abstract}


with significantly higher percent (56.5\%) of high expression of p53 gene mutation of high degree, in addition to higher levels of serum mutant p53 protein and urinary 1OHP. Further analysis of results showed significantly higher urinary 1-OHP and serum mutant p53 protein $(\mathrm{P}<0.005)$ among the workers of mixing and paving than in the group of drivers indicating the impact of dermal absorption among the group of mixing and paving on the internal exposure level of PAHs. Conclusion: In the presence of genetic polymorphisms of cytochrome P4501A1 namely CYP1A1*2A (Valine / Valine) genotype, there is increased susceptibility to higher risk of cancer among people occupationally exposed to PAHs as in asphalt industry.

Key Words: Asphalt-PAHs-CYP1A1- CYP1A1*2A-CYP1A1*1- CYP1A1*2CPolymorphism-P53 gene mutation- Urinary 1-OH Pyrene.

\section{Introduction}

Asphalt pavement refers to any paved road surfaced with asphalt. Hot Mix Asphalt is a combination of approximately $95 \%$ stone, sand, or gravel bound together by asphalt cement, a product of crude oil ${ }^{(1)}$. Asphalt production is dictated by performance specifications rather than by a specific chemical composition. The precise chemical composition and physical properties of the resulting products are influenced by the composition of the original crude petroleum oil and the manufacturing processes. The basic chemical components of crude petroleum oil include paraffinic, naphthenic, and aromatic hydrocarbons as well as heterocyclic molecules containing sulfur, oxygen, and nitrogen. The proportions of these chemical components may vary significantly be- cause sources of crude petroleum oil occur in various locations throughout the world involving different geologic formations Therefore, no two asphalts are chemically identical, and chemical analysis defining the precise structure and size of the individual molecules found in asphalt is almost impossible (2).

Asphalt fumes are defined as the cloud of small particles created by condensation from the gaseous state after volatilization of asphalt. The major route of occupational exposure to asphalt fumes (e.g., paving, roofing, and asphalt-based paints) is by inhalation and may also be through the skin absorption (3).

Exposure to asphalt fumes is a health concern due to the presence of polycyclic aromatic hydrocarbons (PAHs) in asphalt. PAHs are a group of over 100 different 
chemicals that are formed during the incomplete burning of coal, oil and gas, garbage, or other organic substances like tobacco $^{(4)}$. An important and very extensively studied prototype of this class of compounds is benzo (a) pyrene ( $\mathrm{BaP})$. PAHs such as $\mathrm{BaP}$ must be metabolically activated to exert their toxic effects. They are known to be potent substrates for cytochrome P4501A1 enzyme CYP1A1, CYP1B1, glutathione S-transferase M1 (GSTM1), glutathione S-transferase T1 (GSTT1) and microsomal epoxide hydrolase enzymes ${ }^{(5)}$.

CYP1A1, is constitutively nil but ubiquitous after induction by PAHs. Hundreds of studies performed in vitro and in cell culture have demonstrated clearly that CYP1A1 is involved in the metabolic activation of $\mathrm{BaP}$ into reactive intermediates capable of binding to DNA and proteins which are the ultimate carcinogenic diol epoxides (B(a)PDE). Numerous reports have shown that these reactive intermediates, rather than the non metabolized parent compound, are responsible for $\mathrm{BaP}-$ mediated toxicity, mutations, cancer, and birth defects. Exploring the associations between genetic polymorphisms of metabolic enzymes and susceptibility to polycyclic aromatic hydrocarbon (PAH)induced damage is of great significance for understanding PAH carcinogenesis (6).
As the presumed guardian of the genome, the p53 tumor suppressor gene (also known as TP53) coordinates a delicate balance between arrest of the cell cycle to allow repair of damage and apoptosis if the damage is irreparable. Unfortunately, the p53 gene is one of the most commonly mutated genes observed in human tumors. It is mutated in more than $50 \%$ of all human cancers and in about $60 \%$ of human lung cancers. Now, it is clear that, p53 is just one of the components of a network that culminate in tumor formation ${ }^{(7)}$.

\section{Aim of the Work}

This study aimed at evaluating the relationship between exposure markers such as urinary 1-OH pyrene as a marker of internal dose and serum P53 protein as a response marker with the genetic polymorphism of CYP1A1 as a susceptibility marker among asphalt exposed workers.

\section{Subjects \& Methods}

\section{I) Subjects:}

This study was conducted at one of road paving stations located in Pyramids zone, Giza Governorate. Subjects of this study were composed of 43 male workers who constituted the exposed group. They were divided into 2 subgroups, a group of mixing raw materials and spreading the asphalt on the road $(n=24)$ and a group of 
drivers of vehicles and rollers $(n=19)$. Both exposed groups have been exposed to asphalt regularly for at least 2 years. The control subjects $(n=27)$ were randomly selected from the cleaning workers at Cairo University. The controls had no history of occupational exposure to (PAHs) . Both control and exposed groups were matched as regards age, sex, smoking habits, and socioeconomic standard.

\section{II) Methods :}

All participants in the study were subjected to the following:

a) A comprehensive personal and occupational history taking .

b) Laboratory procedures that included:

\section{i) Urinary 1-Hydroxypyrene (1-OHP)}

\section{Analysis}

High performance liquid chromatography (HPLC) with electrochemical detector (waters) was used to measure the urinary 1-hydroxypyrene (1-OHP). Accuracy and precision were assessed using urine reference materials. The concentration of urinary 1-hydroxypyrene at mid-shift was used as an index of exposure. The results of urinary 1-OHP were then corrected for urinary creatinine. A cumulative index of exposure would have been a more reliable index of exposure, being based on the worker's mean 1-OHP for each quarter of the year. Unfortunately, no previous analysis was available. Chromatographic separation was performed using $3 \mu \mathrm{m}$ BAS phase II ODS analytical column (100\# $302 \mathrm{~mm}$ I-D) preceded by $7 \mu \mathrm{m}$ BAS phase II ODS pre column $(15 \# 302 \mathrm{~mm})$. The method involved extraction of $100 \mu$ urine sample with $500 \mu$ perchloric acid containing $0.01 \%$ cystine as antioxidant, 500pg/ $100 \mu 1$ internal standard. The mobile phase consisted of $0.1 \mathrm{M}$ monochloroacetic acid, $0.65 \mathrm{mM}$ sodium octylsulphate, $0.5 \mathrm{mM}$ EDTA per millililter water and $\mathrm{pH}$ was adjusted at 3.05 with $6 \mathrm{~m} \mathrm{NaOH}$. All chemicals were HPLC graded (SIGMA, st Louis, MO, USA). Following filtration through GV $0.22 \mu \mathrm{m}$ filter (waters), acetonitrile was added to a final concentration of $2.9 \%$. The mobile phase was degassed through vaccum degasser (BAS-LC26). The chromatographic separation was performed isocritically at flow rate of $0.1 \mathrm{ml} /$ min The detector potential was 0.45 volt versus silver electrode AG/AG column. Injection volume was $50 \mu 1$.

\section{ii) Detection of cytochrome P450 and} gene expression of mutant $p 53$ by PCR:

\section{DNA extraction:}

Genomic DNA was extracted from 1001 of whole blood by a silica gel col- 
umn method ( QIA amp DNA blood mini kit, Qiagen Gmbh, Hilden, Germany). Extracted DNA was quantitated at $260 \mathrm{~nm}$ by spectro-photometer. This extracted DNA was used for:

\section{a) Gene expression of mutant P 53 .}

The PCR mixture contained $10 \mathrm{mmol} /$ L Tris-Hcl pH 8.3, 50 m M KCL, $1.5 \mathrm{~m} \mathrm{M}$ KCL2, $250 \mu \mathrm{m}$ of DNTPS mixure, $2.5 \mathrm{U}$ of Taq polymerase and $100 \mathrm{uM}$ of each of specific pnmer with the following sequence:

F : 5' ATG GCA GAA GGA GGG CAG AT-3'

\section{R : 5'GAT GTT GAG CGA GAA AGT-3'}

This reaction mixture was then subjected to 40 cycles of $95^{\circ} \mathrm{c}$ for $1 \mathrm{~min}$ and $72^{\circ} \mathrm{c}$ for 2 mins and finally an extension cycle for $10 \mathrm{~min}$ at $72^{\circ} \mathrm{c}$ was done. The PCR product were electrophoresed on 210 agarose gel and visualized by UV transilluminator.

\section{b) Genotyping of cytochrome $\mathbf{P}_{450}$ (CYP1A1) gene :}

The sequence flanking Cyt. $\mathrm{P}_{450}(\mathrm{~T} / \mathrm{V})$ polymorphism were PCR amplified from genomic DNA using a pair of oligonucleotide primers:

5'- CTG GAG ACC ACT CCC ATC CTT TCT-3'.
The PCR was carried out in $10 \mathrm{ul}$ of $10 \mathrm{x}$ buffer containing Tris-HCL, KCL, mg cl $2,2-4$ units of Taq, DNTPS and 100 umol of each primer. After an initial denaturation at $94{ }^{\circ} \mathrm{c}$ for 3 mins, the DNA was amplified by 30 PCR cycles of denaturation at $94^{\circ} \mathrm{c}$ for $30 \mathrm{secs}$, annealing at $58^{\circ} \mathrm{C}$ for $45 \mathrm{secs}$, and extension at $68^{\circ} \mathrm{c}$ for 45 secs, and followed by final extension at $70^{\circ} \mathrm{c}$ for 8 mins.

The PCR products were separated by electrophoresis and visualized by UV Transilluminator. The cytochrome $\mathrm{P}_{450}$ (CYP1A1 2A) (valine / valine) was detected at 490 bp band, the genotype (CYP1A1*2C) (isoleucine / valine) was visualized at $190 \mathrm{bp}$ band, the last type (CYP1A1* 1) (isoleucine / isoleucine) was detected at 153 bp band.

\section{iii) Estimation of $\mathbf{P}_{53}$ level by ELISA:}

Mutant $\mathrm{P}_{53}$ level was measured by ELISA kit supplied by ( Diagnostic Products Corp., Apeldoorn, The Neherlands) according to manufacture's instructions ${ }^{(8)}$.

\section{III ) Statistical analysis:}

The distribution of different CYP1A1 genotypes and expression of p53 gene mutation among the study population, was expressed as frequency distribution using chi 2 test. The serum level mutant p53 protein and the urinary 1-OHP results were 
expressed as means and standard deviations (SD). Analysis of variance (ANOVA) was used for multiple comparisons between the groups. Post-hoc test was then used to study the inter-relation between the different groups. Pearson correlation coefficient was used to relate between the different parameters. A $\mathrm{P}$ value of $<0.05$ was considered to be the level of significance. Computer based statistical package for social sciences (SPSS) for windows 9.1 program was used.

\section{Results}

The study population consisted of 70 male subjects divided into an asphalt exposed group $(\mathrm{n}=43)$ and a control group $(n=27)$. Both groups were matched $(P$ $>0.05$ ) as regards age, smoking index (S.I) (Pack / year) and duration of exposure as shown in Table (1). Concerning pre-shift Urinary hydroxy pyrene (1-OHP) $(\mu \mathrm{g} / \mathrm{mg}$ creatinine) and serum level of mutant p53 protein $(\mathrm{pgmol} / \mathrm{ml})$, both parameters were remarkably higher $(\mathrm{P}<0.001)$ among the exposed versus the control group (1.575士 $1.626,2278.44 \pm 1039.311)$ versus $(0.327$ $\pm 0.625,973.220 \pm 346.710$ ), respectively, the differences being statistically significant (table2). Demonstration of the mean \pm SD of serum level of mutant p53 protein (pgmol/ $\mathrm{ml}$ ) in association with different degrees of expression of mutant p53 gene was presented in table 3 .

Frequency distribution of CYP1A1 genotypes (CYP1A $1 * 2 \mathrm{~A}, \mathrm{CYP} 1 \mathrm{~A} 1 * 2 \mathrm{C}$, CYP1A1*1) was demonstrated in table (4). Workers carrying the genotype CYP1A1*2A, constituted $53.5 \%$ of the exposed workers and $55.5 \%$ of the controls while the other two genotypes constituted less percentages $(21 \%$ for CYP1A $1 * 2 \mathrm{C}$, and $25.5 \%$ for CYP1A1*1). The distribution of the different genotypes did not differ statistically between the control and exposed groups. For the associated degrees of expressed mutant $\mathrm{p} 53$ gene detected by PCR technique among the exposed subjects, high degree of p53 gene mutation (56.5\%) was found among individuals carrying the genotype CYP1A $1 * 2 \mathrm{~A}$, while $43.5 \%$ had moderate expression of p53 gene mutation and none had a low degree of mutation.. The other 2 genotypes, CYP1A $1 * 2 \mathrm{C}$ and CYP1A1*1, showed more per cents of moderate and low degree of gene p53 mutation. As regards Table (5), it shows the mean \pm SD of Urinary (1-OHP), serum level of mutant p53 protein and smoking index (S.I) among different CYP1A1 genotypes. The exposed workers carrying the $\mathrm{CYP} 1 \mathrm{~A} 1 * 2 \mathrm{~A}$ allele showed higher levels of the two parameters $(1.625 \pm 0.536,2756.0 \pm 843.332)$ than those carrying CYP1A $1 * 2 \mathrm{C}$ or 
Table (1): Mean \pm SD of age, duration of exposure (in years) and smoking index (S.I) (Pack / year) among the exposed workers and the control subjects.

\begin{tabular}{|c|c|c|c|c|}
\hline & $\begin{array}{c}\text { exposed } \\
\mathrm{N}=43\end{array}$ & $\begin{array}{c}\text { Control } \\
\mathrm{N}=27\end{array}$ & $\mathrm{t}$ \\
\hline Age & $35.90 \pm 11.052$ & $33.533 \pm 9.164$ & 0.677 & $\mathrm{n} . \mathrm{s}^{*}$ \\
\hline S.I (pack/year) & $8.650 \pm 8.290$ & $7.966 \pm 7.122$ & 0.256 & $\mathrm{n} . \mathrm{s}^{*}$ \\
\hline Duration (in years) & $9.50 \pm 7.330$ & ----- & --- --- $^{*--}$ & \\
\hline
\end{tabular}

Table (2): Mean \pm SD of Urinary hydroxy pyrene (1-OHP) ( $\mu \mathrm{g} / \mathrm{mg}$ creatinine) and serum level of mutant p53 protein ( $\mathrm{pgmol} / \mathrm{ml})$ among exposed and control groups.

\begin{tabular}{|c|c|c|c|c|}
\hline & $\begin{array}{c}\text { Pre-shift exposed } \\
\mathrm{N}=23\end{array}$ & $\begin{array}{c}\text { Control } \\
\mathrm{N}=27\end{array}$ & $\mathrm{t}$ & $\mathrm{P}$ \\
\hline $1-\mathrm{OHP}(\mu \mathrm{g} / \mathrm{mg}$ creatinine $)$ & $1.575 \pm 1.626$ & $0.327 \pm 0.625$ & 2.811 & $0.008^{*}$ \\
\hline P53 protein $(\mathrm{Pg} \mathrm{mol} / \mathrm{ml})$ & $2278.44 \pm 1039.311$ & $973.220 \pm 346.710$ & 4.658 & $0.000^{*}$ \\
\hline
\end{tabular}

*= highly significant $\mathrm{P}<0.005$.

Table (3) : Mean \pm SD of serum level of mutant $\mathrm{p} 53$ protein ( $\mathrm{pgmol} / \mathrm{ml}$ ) in relation to different degrees of expression of p53 gene mutation among exposed group.

\begin{tabular}{|c|c|}
\hline Expression of gene mutation & P53 mutant protein \\
& $(\mathrm{Pg} \mathrm{mol} / \mathrm{ml})$ \\
\hline High degree & $3018.76 \pm 327.95$ \\
\hline Moderate degree & $2251.80 \pm 632.32$ \\
\hline Low degree & $703.75 \pm 117.14$ \\
\hline
\end{tabular}


CYP1A1*1 genotypes but ANOVA test (CYP1A1*2A) and (CYP1A1*2C) regarddid not show statistically significant differ- ing both the urinary 1-OHP and p53 muence as regards the urinary (1-OHP) ( $\mathrm{P}$ tant protein although they were higher in $>0.05)$. Multiple comparison using Post (CYP1A1*2A) genotype, while there was Hoc test for the previous data showed no highly significant difference concerning significant difference $(\mathrm{P}>0.05)$ between them in both CYP1A $1 * 2 \mathrm{~A}$ and CYP1A $1 * 1$ workers with the genotypes genotype (table 6).

Table (4): Frequency distribution of CYP $1 \mathrm{~A} 1$ genotypes (CYP1A1*2A, CYP1A1*2C, CYP1A $1 * 1)$ and the associated degrees of expressed mutant $\mathrm{p} 53$ gene detected by polymerase chain reaction (PCR) technique among the exposed and the control subjects.

\begin{tabular}{|c|c|c|c|c|c|c|c|}
\hline \multirow[t]{2}{*}{$\begin{array}{l}\text { CYP1A1 } \\
\text { genotypes }\end{array}$} & \multirow[t]{2}{*}{$\begin{array}{c}\text { Degree of } \\
\text { P53 mutation }\end{array}$} & \multicolumn{2}{|c|}{$\begin{array}{l}\text { exposed } \\
\mathrm{N}=43\end{array}$} & \multicolumn{2}{|c|}{$\begin{array}{l}\text { Control } \\
\mathrm{N}=27\end{array}$} & \multirow[t]{2}{*}{ Chi 2} & \multirow[t]{2}{*}{$\mathrm{P}$} \\
\hline & & $\mathrm{N}$ & $\%$ & $\mathrm{~N}$ & $\%$ & & \\
\hline \multirow[t]{5}{*}{${ }^{1} \mathrm{CYP} 1 \mathrm{~A} 1 * 2 \mathrm{~A}$} & & 23 & 53.5 & 15 & 55.5 & 0.029 & $\mathrm{n} . \mathrm{s}$ \\
\hline & High & 13 & 56.5 & 1 & 7 & 0.532 & $<0.01$ \\
\hline & Moderate & 10 & 43.5 & 1 & 7 & 0.530 & $<0.01$ \\
\hline & Low & 0 & 0 & 3 & 20 & -- & -- \\
\hline & ${ }^{4}$ None & 0 & 0 & 10 & 66 & -- & -- \\
\hline \multirow[t]{5}{*}{${ }^{2} \mathrm{CYP} 1 \mathrm{~A} 1 * 2 \mathrm{C}$} & & 9 & 21 & 5 & 18.5 & 0.060 & $\mathrm{n} . \mathrm{s}$ \\
\hline & High & 0 & 0 & 0 & 0 & --- & ---- \\
\hline & Moderate & 5 & 55.5 & 1 & 20 & 0.739 & n.s \\
\hline & Low & 4 & 44.5 & 1 & 20 & 0.739 & $\mathrm{n} . \mathrm{s}$ \\
\hline & None & 0 & 0 & 3 & 60 & ---- & ---- \\
\hline \multirow[t]{5}{*}{${ }^{3} \mathrm{CYP} 1 \mathrm{~A} 1 * 1$} & & 11 & 25.5 & 7 & 26 & 0.001 & n.s \\
\hline & High & 2 & 18 & 0 & 0 & ----- & ---- \\
\hline & Moderate & 7 & 64 & 1 & 14 & 0.366 & n.s \\
\hline & Low & 2 & 18 & 2 & 28 & 0.350 & $\mathrm{n} . \mathrm{s}$ \\
\hline & None & 0 & 0 & 4 & 58 & --- & ---- \\
\hline
\end{tabular}

$1=$ Valine $/$ Valine genotype

$2=$ valine/ isoleucin genotype.

$3=$ isoleucin/isoleucin genotype.

$4=$ no detection of $\mathrm{p} 53$ gene mutation. 
Further, the exposed group was divid- $986.03 \mathrm{pg} \mathrm{mol} / \mathrm{ml}$, respectively) compared ed into mixing and paving group $(\mathrm{n}=24)$ to drivers $(0.680 \pm 0.515 \mu \mathrm{g} / \mathrm{mg}$ creatinine, and driver group $(\mathrm{n}=19)$. Both groups were $156.143 \pm 753,581 \mathrm{pg} \mathrm{mol} / \mathrm{ml}$, respectivematched in age , SI and duration of work. ly) $(\mathrm{P}<0.001)$. Multiple comparison using Table (7) reveals that the urinary (1-OHP) Post Hoc test for the previous data. Table and serum level of mutant p53 protein are (8) shows that there was no difference behigher among the asphalt paving workers tween urinary (1-OHP) of the group of $(1.819 \pm 1.385 \mu \mathrm{g} / \mathrm{mg}$ creatinine, $2661.44 \pm \quad$ drivers $(0.680 \pm 0.515 \mu \mathrm{g} / \mathrm{mg}$ creatinine $)$ and

Table (5): Mean \pm SD of Urinary hydroxy pyrene (1-OHP) ( $\mu \mathrm{g} / \mathrm{mg}$ creatinine), serum level of mutant p53 protein (pgmol/ $\mathrm{ml}$ ) and smoking index (S.I) among differtent CYP1A1 genotypes detected among the exposed group.

\begin{tabular}{|c|c|c|c|c|c|}
\hline & $\begin{array}{c}\text { CYP1A1*2A } \\
\mathrm{N}=23\end{array}$ & $\begin{array}{c}\text { CYP1A1*2C } \\
\mathrm{N}=9\end{array}$ & $\begin{array}{c}\text { CYP1A1*1 } \\
\mathrm{N}=11\end{array}$ & $\mathrm{~F}$ & $\mathrm{P}$ \\
\hline 1-OHP & 1.625 & 1.244 & 0.736 & 5.012 & $\mathrm{n} . \mathrm{s}$ \\
$(\mu \mathrm{g} / \mathrm{mg}$ creatinine $)$ & \pm 0.536 & \pm 0.776 & \pm 0.444 & & \\
\hline P53 protein & 2756.0 & 1828.980 & 1436.650 & 10.562 & $<0.05$ \\
$(\mathrm{Pg} \mathrm{mol} / \mathrm{ml})$ & \pm 843.332 & \pm 589.411 & \pm 549.559 & & \\
\hline S.I & 9.00 & 11.20 & 6.000 & 0.523 & $\mathrm{n} . \mathrm{s}$ \\
Pack/year & \pm 8.79 & \pm 8.526 & \pm 8.000 & & \\
\hline
\end{tabular}

Table (6): Multiple comparison using Post Hoc Test between mean \pm SD of Urinary hydroxy pyrene (1-OHP) $(\mu \mathrm{g} / \mathrm{mg}$ creatinine) and serum level of mutant p53 protein (pgmol/ $\mathrm{ml})$ among differtent CYP1A1 genotypes detected among the exposed group.

\begin{tabular}{|c|c|c|c|c|}
\hline & CYP1A1*2A & CYP1A1*2C & CYP1A1*1 & P \\
& $\mathrm{N}=23$ & $\mathrm{~N}=9$ & ------ & \\
\hline 1 -OHP & $1.625 \pm 0.536$ & $1.244 \pm 0.776$ & $0.736 \pm 0.444$ & $\mathrm{n} . \mathrm{s}$ \\
$(\mu \mathrm{g} / \mathrm{mg}$ creatinine $)$ & -------- & $1.244 \pm 0.776$ & $0.736 \pm 0.444$ & $<0.04 *$ \\
\hline $\mathrm{P} 53 \mathrm{protein}$ & $1.625 \pm 0.536$ & ------- & ----- & $\mathrm{n} . \mathrm{s}$ \\
$(\mathrm{Pg} \mathrm{mol} / \mathrm{ml})$ & $2756.0 \pm 843.332$ & $1828.980 \pm 589.411$ & $1436.650 \pm 549.559$ & $\mathrm{n} . \mathrm{s}$ \\
& -------- & $1828.980 \pm 589.411$ & $1436.650 \pm 549.559$ & $<0.007 *$ \\
\hline
\end{tabular}

* statistically significant $\mathrm{P}<0.05$ 
the control $(0.327 \pm 0.625 \mu \mathrm{g} / \mathrm{mg}$ creati- um level of mutant $\mathrm{p} 53$ protein $(\mathrm{r}=0.850$ nine). Also the serum $\mathrm{p} 53$ mutant protein $\mathrm{P}<000$ ). Insignificant correlation was in the asphalt paving workers (2661.44 $\mathrm{pmol} / \mathrm{ml}$ ) was statistically significantly higher than that of group of drivers $(1567.143 \mathrm{pmol} / \mathrm{ml}) \quad(\mathrm{P}<0.05)$.

\section{Discussion}

Inter-variable correlations (table 9) revealed highly significant positive correlation between the urinary (1-OHP) and serfound between the duration of exposure and SI on one hand and the urinary (1OHP) on the other hand.

Asphalt is a mixture of mineral matter and bitumen. Road pavers are exposed to asphalt fumes through dermal contact, in-

Table (7): Mean \pm SD of Urinary hydroxy pyrene (1-OHP) ( $\mu \mathrm{g} / \mathrm{mg}$ creatinine) and serum level of mutant p53 protein ( pgmol/ $\mathrm{ml}$ ) among mixing and paving group, group of drivers and the control subjects.

\begin{tabular}{|c|c|c|c|c|c|}
\hline & $\begin{array}{c}\text { Paving \& } \\
\text { Mixing group } \\
\mathrm{n}=24\end{array}$ & $\begin{array}{c}\text { Vehicles \& } \\
\text { roller drivers } \\
\mathrm{n}=19\end{array}$ & $\begin{array}{c}\text { Control } \\
\text { group } \\
\mathrm{n}=27\end{array}$ & $\mathrm{~F}$ & $\mathrm{P}$ \\
\hline Age & 39.0 & 33.00 & 33.533 & 0.615 & $\mathrm{n} . \mathrm{s}$ \\
& \pm 11.68 & \pm 9.66 & \pm 9.164 & & $\mathrm{n} . \mathrm{s}$ \\
\hline Duration & 10.750 & 8.571 & ------ & 0.165 & $\mathrm{n} . \mathrm{s}$ \\
(in years) & \pm 7.472 & \pm 7.184 & & & \\
\hline S.I & 8.416 & 10.285 & 7.966 & 0.264 & $<0.001$ \\
$($ pack/year) & \pm 7.864 & \pm 9.411 & \pm 7.122 & & \\
\hline 1-OHP & 1.819 & 0.680 & 0.327 & 21.55 & $<0.001$ \\
$(\mu \mathrm{g} /$ mg creatinine $)$ & \pm 1.385 & \pm 0.515 & \pm 0.625 & & \\
\hline P53 protein & 2661.44 & 156.143 & 973.220 & 19.145 & \\
$(\mathrm{pg}$ mol/ ml $)$ & \pm 986.03 & \pm 753.581 & \pm 346.710 & & \\
\hline
\end{tabular}


Table (8): Multiple comparison using post Hoc test between mean \pm SD of Urinary hydroxy pyrene (1-OHP) ( $\mu \mathrm{g} / \mathrm{mg}$ creatinine) and serum level of mutant 553 protein $(\mathrm{pg} / \mathrm{ml})$ among mixing and paving group, group of drivers and the control subjects.

\begin{tabular}{|c|c|c|c|c|}
\hline & $\begin{array}{c}\text { Paving \& Mixing group } \\
\mathrm{n}=24\end{array}$ & $\begin{array}{c}\text { Vehicles \& roller drivers } \\
\mathrm{n}=19\end{array}$ & $\begin{array}{c}\text { Control group } \\
\mathrm{n}=27\end{array}$ & $\mathrm{P}$ \\
\hline 1 -OHP & $1.819 \pm 1.385$ & $0.680 \pm 0.515$ & ------- & $<0.005$ \\
$(\mu \mathrm{g} / \mathrm{mg}$ & ------- & $0.680 \pm 0.515$ & $0.327 \pm 0.625$ & $\mathrm{n} . \mathrm{s}$ \\
creatinine $)$ & $1.819 \pm 1.385$ & ------ & $0.327 \pm 0.625$ & $<0.001$ \\
\hline P53 protein & $2661.44 \pm 986.03$ & $156.143 \pm 753.581$ & ----- & $<0.001$ \\
$(\mathrm{pg} / \mathrm{ml})$ & ------- & $156.143 \pm 753.581$ & $973.22 \pm 346.710$ & $\mathrm{n} . \mathrm{s}$ \\
& $2661.44 \pm 986.03$ & ------- & $973.22 \pm 346.710$ & $<0.001$ \\
\hline
\end{tabular}

Table (9): Correlation coefficient ${ }^{\circledR}$ between duration of exposure, smoking index (SI), and urinary 1-OHP with serum level of mutant $\mathrm{p} 53$ protein among the exposed workers.

\begin{tabular}{|c|c|c|}
\hline & $1-\mathrm{OHP}$ & P53 protein \\
\hline Duration of & $\mathrm{R}=0.104$ & ---- \\
exposure & $\mathrm{P}>0.05^{*}$ & ---- \\
\hline SI & $\mathrm{R}=0.062$ & \\
\hline Pack/year & $\mathrm{P}>0.05^{*}$ & $\mathrm{R}=0.850$ \\
\hline 1-OHP & ------ & $\mathrm{P}<000^{* *}$ \\
\hline
\end{tabular}

* no statistical significance

** high statistical significance

halation, or ingestion. These fumes contain polycyclic aromatic compounds (PACs), a class of compounds including polycyclic aromatic hydrocarbons (PAHs). The PAHs include compounds such as pyrene and benzo (a) pyrene and a large number of other compounds of known or suspected carcinogenicity $(9)$. Prolonged, extensive exposure to asphalt fume has been associated with several adverse health ef- loss of these essential functions and ulti- fects. Emitted (PAHs) from asphalt fumes have been suspected of inducing such effects $(10)$.

In vitro genotoxicity and mechanistic studies demonstrated a mutagenic effect of bitumen fume condensates (BFC). However, accumulation of mutations in genes responsible for the maintenance of growth control and genomic integrity results in 
mately leads to tumor formation. In 2001, the results of the IARC epidemiological study confirmed an excess of lung cancer despite a lower cancer mortality. Some studies provided a suggestive evidence of an excess risk of bladder cancer among asphalt workers (11).

It is widely held that humans differ in their susceptibilities to cancer. This may be due to a number of factors including health, nutritional status, and gender. From what is known about the mechanism of action of carcinogens, it is thought that genetic background could play a significant role. Variable levels of expression of genes that are encoding the xenobioticmetabolizing enzymes (XMEs) could result in increased or decreased carcinogen activation (12). The cytochrome P450 (CYP)-dependent monooxygenases represent the first line of defense against toxic lipophilic chemicals. Unfortunately, certain chemicals are activated to their ultimate carcinogenic form rather than being detoxified. The main CYPs in humans that metabolize carcinogens are CYP1A1, CYP1A2, CYP1B1, CYP2A6, CYP2E1, CYP3A4, and CYP3A5 (13).

The CYP1A gene family has two members: CYP1A1, which is predominantly expressed in extrahepatic tissues such as the lung, and CYP1A2, which is concentrated in the liver (22). CYP1A1 is involved, e.g., in the metabolic activation of polycyclic aromatic hydrocarbons (PAHs) to their carcinogenic metabolites in the lung(14). As an example, CYP1A1dependent aryl hydrocarbon hydroxylase (AHH) activities in human lung tissue (microsomes) correlate with activation of benzo(a)pyrene 7,8-diol to the ultimate carcinogen. Furthermore, the AHH activities correlate with the benzo(a)pyrene 7,8-diol9,10-epoxide (BaPDE) DNA adduct levels in human lung tissue (15). Moreover, some results demonstrate that asphalt fume condensate (AFC) exposure induced CYP1A1 activity and increased the enzyme levels of CYP1A1 in lung microsomes, suggesting that AFC exposure may alter metabolism of PAHs by the cytochrome P-450 system in the lung. Alteration of cytochrome P450 metabolism of PAHs may contribute to the AFC-induced genotoxic effects demonstrated as micro nuclei (MN) formation (16).

In recent years the impact of inherited polymorphisms in the CYP1A1 gene on susceptibility to lung cancer has received particular interest since this enzyme plays a central role in the metabolic activation of (PAHs). Three common polymorphisms of the CYP1A1 have been identified and several systematic nomenclatures for 
CYP1A1 have been proposed. The CYP1A1 $\mathrm{m} 1$ as CYP1A1*2, CYP1A1*2A or Valine / Valine genotype, CYP1A1 M2 as CYP1A1*2C or Isoluecin / Valine genotype, and wild type as CYP1A $1 * 1$ or Isoluecine / Isoluecine genotype $^{(17)}$.

In the current study, polymerase chain reaction (PCR) analysis of the CYP1A1 gene revealed that $\mathrm{CYP} 1 \mathrm{~A} 1 * 2 \mathrm{~A}$ (valine / valine ) genotype constitutes $53.5 \%(n=23$ out of 43)of the exposed workers versus, $21 \%$ for the CYP1A $1 * 2 \mathrm{C}$ ( $\mathrm{n}=9$ out of 43 ) and $25.5 \% \quad(n=11$ out of 43$)$ for CYP1A1*1 indicating that it is the most prevalent genotype among the study subjects particularly if this percentages did not differ significantly from that of the controls ( 55.5\%, $18.5 \%$ and 26\%), respectively (table 3). Genotype frequencies were known to vary by geography and race. However, many studies reported the rarity of CYP1A $1 * 2 \mathrm{C}$ genotype among the Caucasian populations compared to Asians (18). Besides, Alexandrie et al.,(5) reported the predominance of CYP1A $1 * 2 \mathrm{~A}$ among the Caucasians.

On the other hand, PCR analysis of the p53 gene revealed different degrees of expression of p53 gene mutation ranging from high, moderate to low degree among the whole exposed population. Workers carrying the genotype CYP1A $1 * 2 \mathrm{~A}$ (valine /valine) showed the highest percent of expressing high degree of p53 gene mutation $(56.5 \%)$ while $43.5 \%$ had moderate expression of p53 gene mutation. None of the exposed individuals carrying this genotype had low degree of mutation. The other 2 genotypes showed statistically significantly higher percentage of moderate and low degree of gene p53 mutation compared to controls. This mutation can be explained by studies that have demonstrated that, B(a)PDE induces guanine adducts at mutational hotspots, including codons 157 , 248 , and 237 of p53 gene in normal human bronchial epithelial cells. Recently, Alexanerov et al.,(19) reported that, the persons with CYP1A1*2A -GSTM1 null genotype combination had higher level of BDPEDNA adducts . Additionally, this is consistent with the prevalence of G:T mutations in the p53 gene at the hotspot codons in the lung tumors of smokers (being exposed to PAHs), a point mutation that is indicative of PAHs related mutational damage (20). What complicates the situation, is that in the p53 gene the same codons are preferential targets for not only mutagenesis but also tumorigenic selection(7).

Therefore, It was not surprising to find out this remarkable increase in the serum level of mutant p53 gene protein among 
the exposed workers $(2278.44 \pm 1039.311$ versus $973.220 \pm 346.710$ in the controls) $(\mathrm{P}<0.000)$ (table 2). Our results correspond with Rossener et al., (21) who detected a significant increase in p53 proteins (the mutant and the wild types) in workers exposed to carcinogenic PAHs $>1$ microg/ $\mathrm{m} 3$ as compared with the group exposed to carcinogenic PAHs $<1 \mathrm{microg} / \mathrm{m} 3$. A similar trend was observed for p21(WAF1) protein, eventhough no correlation exists between the levels of both proteins.

Normally, p53 protein regulates the transcription of genes responsible for cell cycle arrest and apoptosis. P53 protein binds DNA, which in turn stimulates another gene to produce a protein called $\mathrm{p} 21$ that interacts with a cell divisionstimulating protein (cdk2). When p21 is complexed with cdk2; it induces cell cycle arrest either in the $G(1), S$, or $G^{(2)}$ phases $^{(22)}$.Mutant p53 can no longer bind DNA in an effective way, and as a consequence the $\mathrm{p} 21$ protein is not made available to act as the 'stop signal' for cell division. Thus cells divide uncontrollably, and form tumors $(21)$.

However, it has been shown that carcinogenic $\mathrm{B}(\mathrm{a})$ pyrene is able to induce the expression of both p53 and p21(WAF1) proteins in vitro .This induction occurs subsequent to the induction of DNA ad- ducts which are correlated with both p53 and p21(WAF1) levels regardless of the $\mathrm{PAH}$ exposure and the phase of cell growth. This induction requires a minimal DNA adduct level of approximately 200250 adducts/10 nucleotides for PAHs tested suggesting that the level of adducts rather than their structure triggers the p53 and $\mathrm{p} 21(\mathrm{WAF} 1)$ responses ${ }^{(22)}$.

As pyrene is a major component of most PAH mixtures, it is often used as a indicator for total exposure. Accordingly, many studies have confirmed urinary 1hydroxypyrene (1-OHP) as a biological measure for the internal exposure of $(\mathrm{PAHs})^{(23)}$. Pyrene undergoes simple metabolism and is rapidly bio-transformed into various metabolites that undergo major enterohepatic recycling. Part of the initially formed and part of the recirculated 1OHP eventually undergo urinary excretion such that close to $60 \%$ of pyrene is eliminated as metabolites in urine by $24 \mathrm{~h}$ after exposure while $20 \%$ is excreted in the feaces over the same period (24).

In the current work, there was highly significant statistical difference $(\mathrm{P}<0.001)$ between the mean level of pre-shift urinary (1-OHP) among exposed workers $(n=43)$ $(1.575 \pm 1.626 \mu \mathrm{g} / \mathrm{mg}$ creatinine) compared to control subjects $\quad(n=27) \quad(0.327 \pm$ $0.625 \mu \mathrm{g} / \mathrm{mg}$ creatinine) (table 2). These 
levels are comparable to results obtained by Mc Clean et al.,(25) . The authors detected $(1.4 \mu \mathrm{g} / \mathrm{mg}$ creatinine) of 1-OHP among paving workers in the pre-shift samples taken on the 4th day of the working week which was 3.5 times higher than the results of day 1 . The level of urinary 1hydroxypyrene (1-OHP) was significantly higher in the post-shift samples compared to the pre-shift samples and the controls in another study made by Vaananen et al.,(26) . indicating the reliability of using (1-OHP) as a biological indicator for PAHs exposure. Unfortunately, it was not feasible to perform post- shift sampling in our study.

When 1-OHP level were related with CYP1A1 genotypes, an association was observed for the CYP1A1*2A genotype, so that the asphalt exposed workers carrying the CYP1A $1 * 2 \mathrm{~A}$ allele showed significantly higher 1-OHP levels than those carrying $\mathrm{CYP} 1 \mathrm{~A} 1 * 2 \mathrm{C}$ or CYP1A $1 * 1$ genotypes. This is in accordance with Adonis et al.,(27) who detected no significant correlation between urinary 1-OHP levels and GSTM1 null genotype, although higher levels of the urinary metabolite were found in individuals carrying the combined CYP1A1*2A and GSTM1 null genotype. This suggests an association between levels of the exposure bio- marker 1-OHP and presence of the CYP1A1*2A genotype, as a potential genetic susceptibility biomarker which might be useful in identifying individuals at higher risk among people exposed to high $\mathrm{PAH}$ levels in paving occupation. In addition, CYP1A1*2A genotype exhibited a higher cytokinesis - block micronucleus ( CBMN ) frequency than in CYP1A1*1 (Ile/Ile) or (Ile/Val) CYP1A1*2C genotypes(29). Most reports from Japan point to the strong association between CYP1A1 *2A with the risk of lung cancer, especially in relation to tobacco smokers and in lung squamous cell carcinoma(15) .

Other studies reported that, the highest 1-OHP levels were observed in individuals carrying the CYP1A1 Ile/Val (CYP1A1*2C ) genotype who were also of the GSTM1 null Genotype ${ }^{(29)}$. In the current work, there was no significant difference $(\mathrm{P}>0.05)$ (table 5) between workers with the genotypes (CYP1A $1 * 2 \mathrm{~A})$ and $(\mathrm{CYP} 1 \mathrm{~A} 1 * 2 \mathrm{C})$ regarding both the urinary 1-OHP and p53 mutant protein although they were higher in $(\mathrm{CYP} 1 \mathrm{~A} 1 * 2 \mathrm{~A})$ genotype $\quad(1.625 \pm 0.536 \mu \mathrm{g} / \mathrm{mg} \quad$ creatinine, $2756.0 \pm 843.332 \mathrm{pgmol} / \mathrm{ml})$ versus $(1.244$ $\pm 0.776 \mu \mathrm{g} / \mathrm{mg}$ creatinine,, $1828.98 \pm 589.411$ $\mathrm{pgmol} / \mathrm{ml})$ in $(\mathrm{CYP} 1 \mathrm{~A} 1 * 2 \mathrm{C})$.

This variation in enzyme inducibility could be due to genetic polymorphism in CYP1A1 or in genes involved in the con- 
trol of its expression. Some studies showed effects of glutathione S- transferase (GST) M1 and aryl hydrocarbon polymorphisms on CYP1A1 activity, while others found no key role of these polymorphisms in CYP1A1 inducibility (30). Other studies reported less association between the concentrations of 1-OHP and the GSTM1, polymorphism but these research pointed to a ratio between CYP1A1 and GST enzyme activities as a critical determinant of the target dose of carcinogenic BPDE (31).

Further analysis of the results, revealed higher levels of urinary (1-OHP) among the asphalt paving workers (1.819 \pm $1.385 \mu \mathrm{g} / \mathrm{mg}$ creatinine) compared to workers involved in maintenance and drivers $(0.680 \pm 0.515 \mu \mathrm{g} / \mathrm{mg}$ creatinine $)(\mathrm{P}<0.005)$ (table, 6). The variation in PAHs contamination on the skin may explain this significant difference as many studies have suggested dermal exposure to be a major determinant of the total PAH dose absorbed by road pavers from bitumen fumes $(32,33)$. Vanrooij et al., (34) concluded that an average of $75 \%$ of the total absorbed amount of pyrene enters the body through the skin. Furthermore, dermal exposure that occurred during the preceding $32 \mathrm{~h}$ had a statistically significant effect on urinary 1-OHP, while the effect of inhala- tion exposure was not significant ${ }^{(25)}$. However, among the asphalt exposed workers inhalation and dermal PAHs exposures varied significantly by task, crew, work rate (inhalation only). The inhalation exposures were consistent with the workers' proximity to the primary source of asphalt fume while the dermal exposures were consistent with the degree to which the workers have actual contact with asphalt-contaminated surfaces ${ }^{(35)}$. Usually, paving workers had inhalation (mean 0.3 micro $\left.\mathrm{g} / \mathrm{m}^{3}\right)$ and dermal $\left(5.7 \mathrm{ng} / \mathrm{cm}^{2}\right)$ exposures to pyrene ${ }^{(36)}$.

On the other hand, there was no difference between urinary (1-OHP) of the group of drivers $(0.680 \pm 0.515 \mu \mathrm{g} / \mathrm{mg}$ creatinine $)$ and the control $(0.327 \pm 0.625 \mu \mathrm{g} / \mathrm{mg}$ creatinine). As was discussed before, the exposure of the group of drivers is mainly through inhalation of PAHs which is far less than the dermal absorption making the drivers have higher levels but statistically not significantly different from the controls ( $\mathrm{P}>0.05$ ). Additionally, it should be taken into consideration that PAHs constitute about $1 \%$ of asphalt fumes while the remaining $99 \%$ is formed by aliphatic straight chain hydrocarbons ${ }^{(37)}$.

Similarly, the serum p53 mutant protein in the asphalt paving workers (2661.44 $\mathrm{pmol} / \mathrm{ml}$ ) was statistically significantly 
higher than that of group of drivers $(1567.143 \mathrm{pmol} / \mathrm{ml}) \quad(\mathrm{P}<0.05)$. This can be explained by the lower level of urinary 1OHP detected in this group. In support of these results is the positive significant correlation detected between the urinary (1OHP) and the serum level of mutant p53 protein $(r=0.580, P=0.007)$. This is consistent with the study of Pan et al. who demonstrated a significant correlation between serum p53 protein levels and the cumulated benzo(a)pyrene exposure dose ${ }^{(38)}$.

Inter-variable correlations between the data revealed no significant correlation between the smoking index versus the urinary 1- OHP ( $\mathrm{r}=0.0262 \mathrm{P}>0.05)$, figure (2). Similarly, Lu et al . (39) reported no significant effect of smoking on the excretion of urinary(1-OHP) among coke oven workers but other studies reported that smoking caused a significant increase of urinary $1-\mathrm{OHP}^{(40)}$.

Again no significant correlation was obtained between the level of 1-OHP and the exposure duration in spite of excessive exposure as evidenced by high 1-OHP levels in urine. In similar studies, no statistically significant correlation was observed between biomarker levels and the level of individual PAHs among exposed population $^{(41)}$. Besides, in a longitudinal study on PAH biomarker levels, it was reported that urinary 1-OHP has a day-to-day and weekto-week individual variation, indicating the necessity for multiple sampling (42).

The highly significant positive correlation $(r=0.850, \mathrm{P}<0.001)$ detected between the urinary 1- OHP and serum mutant p53 protein suggest the necessity of using urinary 1- OHP in biological monitoring with the intention to prevent excessive occupational exposure to PAHs. Besides, genetically based metabolic polymorphisms must be taken into account in the future as detected from the higher level of urinary 1-OHP, high degree of p53 gene mutation and the high level of serum p53 mutant protein among individuals carrying CYP1A $1 * 2 \mathrm{~A}$ genotype.

The current work recommends using control strategies that focus on reduction of dermal contamination by PAHs than on the reduction of inhaled dose to reduce occupational exposure to asphalt-related PAHs. An exposure assessment of PAHs that does not consider dermal exposure may considerably underestimate cumulative exposure.

However, the small size of the study limits the potential application of the results to the asphalt industry in general. More research is needed to develop a valid and inexpensive method of assessing total bitumen exposure and susceptibility to the encountered potential hazards . 


\section{References}

1. Melius J. (2003) : Asphalt--a continuing challenge. Am J Ind Med. 43(3):235-6.

2. ACGIH (1991). Asphalt fumes. In: Documentation of the threshold limit values and biological exposure indices, 6th ed. Vol. I. Cincinnati, $\mathrm{OH}$ : American Conference of Governmental Industrial Hygienists, pp. 95-96.

3. Krasniuk EP, Cherniuk VI, Rossinskaia LN, and Chui TS. (2000) : The effect of manufacturing factors in asphalt-bitumen plants on the health of the workers. Lik Sprava. (2):106-12.

4. Cavallo D, Ursini CL, Bavazzano P, Cassinelli C, Frattini A, Perniconi B, Di Francesco A, Ciervo A, Rondinone B, and Iavicoli S. (2005): Sister Chromatid Exchange and Oxidative DNA Damage in Paving Workers exposed to PAHs. Ann Occup Hyg.; (Epub ahead of print)

5. Alexandrie A-K, Nyberg F, Warholm M, and Rannug A, (2004): Influence of CYP1A1, GSTM1, GSTT1, and NQO1 Genotypes and Cumulative Smoking Dose on Lung Cancer Risk in a Swedish Population. C E B P .13: 908-914.

6. Uno S, Timothy P, Derkenne S, Curran C, Miller M, Howard G. and Daniel W. (2004): Oral Exposure to Benzo(a)pyrene in the Mouse: Detoxication by Inducible Cytochrome P450 Is More Important Than Metabolic Activation. Mol Pharmacol 65:1225-1237.

7. Rodin SN, and Rodin AS. (2005): Origins and selection of p53 mutations in lung carcinogenesis. Semin Cancer Biol. 2005 Apr;15(2):103-12.
8. Srinivas G, Kusumakumary P, Nair HR and Pillai MK (2000): Mutant P53 protein, Bcl-2/ Bax ratios and apoptosis in paediatric acute lymphoblastic leukemia. J. Cancer Res. Clin. Oncol. 126 (1): 62-67.

9. Armstrong B, Hutchinson E, Unwin J, and Fletcher T. (2004): Lung cancer risk after exposure to polycyclic aromatic hydrocarbons: a review and meta-analysis. Environ Health Perspect. 112(9): 970-8.

10. Kriech AJ, Kurek JT, Wissel HL, Osborn LV, and Blackburn GR.(2002): Evaluation of worker exposure to asphalt paving fumes using traditional and nontraditional techniques. AIHA J .63(5):628-35.

11. Binet S, Pfohl-Leszkowicz A, Brandt H, Lafontaine M, and Castegnaro M.Sci ( 2002): Bitumen fumes: review of work on the potential risk to workers and the present knowledge on its origin. Total Environ. 300(1-3):37-49.

12. Gonzalez FJ. (1995): Genetic Polymorphism and Cancer Susceptibility: Fourteenth Sapporo Cancer Seminar. Cancer Res 55:710-715 .

13. Finnish Institute of Occupational Health, Helsinki, Finland (1999): Polymorphisms of Xenobiotic-Metabolizing Enzymes and Susceptibility to Cancer. Environ Health Perspect 107(Suppl 1):37-47 .

14. Landi S. (2000):Mammalian class GST and differential susceptibility to carcinogens: a review. Mutat Res Rev Mutat Res 2000;463:247-83.

15. Bartsch H, Nair U, Risch A, Rojas M, Wikman H, and Alexandrov K: (2000):Genetic polymor- 
phism of CYP genes, alone or in combination, as a risk modifier of tobacco-related cancers. Cancer Epidemiol Biomarkers Prev 9:3-28.

16. Ma JY, Yang HM, Barger MW, Siegel PD, Zhong BZ, Kriech AJ, and Castranova V. (2002): Alteration of pulmonary cytochrome p450 system: effects of asphalt fume condensate exposure. J Toxicol Environ Health A. 65 (17):1247-60.

17. Li Y, Robert C, Douglas, Cui L, and Chiu-Kit J, (2004): Cigarette smoking, cytochrome P4501A1 polymorphisms, and breast cancer among African-American and white women. Breast Cancer Res 6 : 460-473.

18. Cascorbi I, Brockmöller J, and Roots I. A (1996): C4887A polymorphism in exon 7 of human CYP1A1: population frequency, mutation linkages, and impact on lung cancer susceptibility. Cancer Res 56:4965-4969 .

19. Alexandrov K, Cascorbi I, Rojas M, Bouvier G, Kriek E, and Bartsch H. (2002) : CYP1A1 and GSTM1 genotypes affect benzo(a)pyrene DNA adducts in smokers' lung: comparison with aromatic/hydrophobic adduct formation. Carcinogenesis. 23(12):1969-77.

20. Smith L, Denissenko M, Benett W, Li H, and Amin S, (2000): Targeting of lung cancer mutational hotspots by polyaromatic hydrocarbons. J. Nation. Cancer institute 92(10):803-811.

21. Rossner P Jr, Binkova B, and Sram RJ. (2003): The influence of occupational exposure to PAHs on the blood plasma levels of p53 and p21WAF1 proteins. Mutat Res. 535(1):87-94.
22. Binkova B, Gigere Y, Rossner P, and Dostal M, (2000): The effect of dibenzo a pyrene and dibenzo pyrene on human diploid lung fibroblasts: the induction of DNA adducts, expression of p53 and $\mathrm{p} 21$ proteins and cell cycle distribution. $\mathrm{Mu}$ tat. Res.471(1-2):57-70.

23. Wang JJ, Frazer DG, Stone S, Goldsmith T, Law B, Moseley A, Simpson J, Afshari A, and Lewis DM.( 2003): Urinary benzo(a)pyrene and its metabolites as molecular biomarkers of asphalt fume exposure characterized by microflow LC coupled to hybrid quadrupole time-of-flight mass spectrometry. Anal Chem. 1;75(21):595360 .

24. Jongeneelen F.J. (2001): Benchmark guideline for urinary 1-hydroxypyrene as biomarker of occupational exposure to polycyclic aromatic hydrocarbons. Ann. Occup. Hyg. 45(1):3-13.

25. McClean MD, Rinehart RD, Ngo L, Eisen EA, Kelsey KT, Wiencke JK, and Herrick RF. (2004): Urinary 1-hydroxypyrene and polycyclic aromatic hydrocarbon exposure among asphalt paving workers. Ann Occup Hyg. 48(6):565-78.

26. Vaananen V, Hameila M, Kontsas H, Peltonen K, and Heikkila P. (2003): Air concentrations and urinary metabolites of polycyclic aromatic hydrocarbons among paving and remixing workers. J Environ Monit. 5(5):739-46.

27. Adonis M, Martinez V, Riquelme R, Ancic P, Gonzalez G, Tapia R, Castro M, Lucas D, Berthou F,and Gil L. (2003): Susceptibility and exposure biomarkers in people exposed to PAHs from diesel exhaust. Toxicol Lett. 144(1):3-15. 
28. Viezzer C, Norppa H, Clonfero E, Gabbani G, Mastrangelo G, Hirvonen A, and Celotti L. (1999): Influence of GSTM1, GSTT1, GSTP1, and EPHX gene polymorphisms on DNA adduct level and HPRT mutant frequency in coke-oven workers. Mutat Res. 431(2):259-69.

29. Alexandrie AK, Warholm M, Carstensen U, Axmon A, Hagmar L, and Levin JO, Ostman C. (2000): CYP1A1 and GSTM1 polymorphisms affect urinary 1-hydroxypyrene levels after PAH exposure. Carcinogenesis. 21(4):669-76.

30. Hirvonen A. (1997): Combinations of Susceptible Genotypes and Individual Responses to Toxicants. Envir. H. Pers. 105(Suppl 4):755-758.

31. Smith,G.B.J., Harper,P.A., Wong,J.M.Y., Lam,M.S.M., Reid,K.R., Petsikas,D. and Massey,T.E. (2001): Human lung microsomal cytochrome P4501A1 (CYP1A1) activities: impact of smoking status and CYP1A1, arylhydrocarbon receptor and glutathione S-transferase M1 genetic polymorphisms. Cancer Epidemiol. Biomarkers Prev., 10, 839-853.

32. Cirla PE, Martinotti I, Zito E, Prandi E, Buratti M, Longhi O, Fustinoni S, Cavallo D, Ariano E, Cantoni S,and Foa V.(2005): Assessment of exposure to organic aromatic compounds and $\mathrm{PAH}$ in asphalt industry: the PPTP-POPA Study results G Ital Med Lav Ergon. 2005 Jul-Sep;27 (3):303-7.

33. Vaananen V, Hameila M, Kalliokoski P, Nykyri E, and Heikkila P.(2005): Dermal exposure to polycyclic aromatic hydrocarbons among road pavers. Ann Occup Hyg. 49(2):167-78.

34. VanRooij JG, Bodelier-Bade MM, and Jonge- neelen FJ. (1993): Estimation of individual dermal and respiratory uptake of polycyclic aromatic hydrocarbons in 12 coke oven workers. $\mathrm{Br} \mathbf{J}$ Ind Med. 50(7):623-32.

35. McClean MD, Rinehart RD, Ngo L, Eisen EA, Kelsey KT, Herrick RF. (2004): Inhalation and dermal exposure among asphalt paving workers. Ann Occup Hyg. 48(8):663-71.

36. Vaananen V, Elovaara E, Nykyri E, Santonen T, and Heikkila P. (2006): Road pavers' occupational exposure to asphalt containing waste plastic and tall oil pitch. J Environ Monit.8(1):8999.

37.Refat A, Hassan A, Soliman N, ELMor A, Mohamed M, and Abass,R, (2003): Occupational renal dysfunction among asphalt workers in Sharkia Governorate :an epedimiological study. Egypt. J. Occup. Med. 27(1): 1-16

38. Pan G, Hanaoka T, Yamano Y, Hara K, Ichiba M, Wang Y, Zhang J, Feng Y, Shujuan Z, Guan D, Gao G, Liu N, Takahashi K. (1998) : A study of multiple biomarkers in coke oven workers--a cross-sectional study in China. Carcinogenesis. 19(11):1963-8.

39. Lu PL, Chen ML, Mao IF. (2002): Urinary 1hydroxypyrene levels in workers exposed to coke oven emissions at various locations in a coke oven plant. Arch Environ Health. 57 (3):255-61.

40. van Delft JH, Steenwinkel MS, van Asten JG, de Vogel N, Bruijntjes-Rozier TC, Schouten T, Cramers P, Maas L, van Herwijnen MH. (2001): Biological monitoring the exposure to polycyclic aromatic hydrocarbons of coke oven workers in 
relation to smoking and genetic polymorphisms for GSTM1 and GSTT1. Ann Occup Hyg. 45 (5):395-408.

41.Ruchirawa M., Mahidol C., Tangjarukij C., Puiock S., Jensen O., Kampeerawipakorn O., Tuntaviroon J., Aramphongphan A. and Autrup H. (2002): Exposure to genotoxins present in ambi- ent air in Bangkok, Thailand-particle associated polycyclic aromatic hydrocarbons and biomarkers. Sci. Total Environ. 287(1-2):121-32.

42. Carmella S.G., Le K.A. and Hecht S.S. (2004): Improved method for determination of 1hydroxypyrene in human urine. Cancer Epidemiol. Biomarkers Prev. 13(7):1261-4. 